\section{Structural-Functional Correlations of the Lung in Horses with Small Airway Disease}

\author{
L. Viel \\ Department of Clinical Studies, Ontario Veterinary College, \\ University of Guelph
}

Chronic obstructive pulmonary diseases have long been recognized as afflictions of stabled horses $(1,2,6)$. There are, however, very few investigations demonstrating the clinical and pathological cause and effect of a suspected etiologic agent(s). Several literature reviews recognized the multifactorial etiology of chronic obstructive lung diseases $(4,5,6,12,17)$, but again, the pathogenesis remains hypothetical. There is clinical evidence that an allergic component is involved $(4,13,20)$, but there is no firm evidence such as cytology, proper histopathological examination or long-term follow up of a specific group of animals to support the diagnosis of an asthmoid-type reaction.

The purpose of this study was, therefore, to define and categorize the chronic lung disorders of horses using respiratory function techniques, fiberoptic bronchoscopy, qualitative and quantitative cytological evaluation of samples obtained by bronchoalveolar lavage, and finally a semiquantitative detailed histological examination of the respiratory system.

\section{Materials and Methods}

Experimental animals consisted of 24 mature light horses: eleven were in the control group and thirteen in the diseased animal group. Horses were mainly gelding and female standardbreds and thoroughbreds, weighing between $375-580 \mathrm{~kg}$ and aged between three and ten years old. Prior to pulmonary function testing (PFT) and bronchoalveolar lavage (BAL), the clinical respiratory status of the horses was established; first, by a detailed resting respiratory examination and, secondly, by an exercise test where horses were lunged for fifteen to twenty minutes. Signs of spontaneous cough, flaring of the nostrils and intolerance to this mild work were noted. Immediately after the exercise test, the respiratory rate was recorded and the trachea and chest were re-auscultated for the presence of any abnormal sounds. During the period of post-exercise recovery, the respiratory rate was monitored and the total time for a complete return to the normal rate was recorded in each instance. In addition, bronchoscopy was performed under mild sedation with xylazine $(.75 \mathrm{mg} / \mathrm{kg}$ intravenously) to detect any abnormalities in the nasopharynx and any presence of purulent exudate at the level of the trachea and bronchi. Percussion was performed and interpreted as having normal, decreased or increased resonance.

\section{Pulmonary Function Tests:}

Pulmonary function testing was performed in conscious, unsedated horses. Lung function studies were carried out twice, i. e., before bronchoalveolar lavage and again four to five days after bronchoalveolar lavage. The materials and methods of pulmonary function tests used were identical to those of Willoughby and McDonell (1979). In summary, the pulmonary function parameters tested were:

1) Lung volume: FRC

2) Ventilation: $V_{T}, f, V_{E}$

3) Pulmonary mechanics: $W_{b}, M i n . W_{b}, C_{D y n}, V_{I} *, V_{E} *$, $\mathrm{R}_{\mathrm{aw}}$

4) Gas distribution: $\left[\mathrm{N}_{2} \%\right]_{\text {end }}$

5) Pulmonary gas exchange:

- resting arterial blood gas $\left(\mathrm{pH}, \mathrm{CO}_{2}\right.$ and $\left.\mathrm{O}_{2}\right)$

- arterial blood gas while the horse breathed $100 \% \mathrm{O}_{2}$

- alveolar-arterial $\mathrm{O}_{2}$ tension difference $\left(\mathrm{A}-\mathrm{aDO}_{2}\right)$

\section{Bronchoscopy and Lung Lavage}

Horses were kept standing in stocks and sedated with xylazine $(1 \mathrm{mg} / \mathrm{kg})$ and morphine $(.75 \mathrm{mg} / \mathrm{kg}$ to a total maximum dose of $300 \mathrm{mg}$ ). Bronchoscopies were performed with a flexible fiberoptic bronchoscope (Olympus CF type LB 2) which was cold sterilized prior to each use. Following bronchoscopic examination of the naso-pharynx, larynx, trachea and mainstem bronchi, the tip of the bronchoscope was positioned in a segmented bronchus of the caudal lobe of the right lung where lung lavage was performed. The lavage consisted of infusing $500 \mathrm{ml}$ of .9\% sterile saline into the lung, and then the fluid was immediately aspirated with a negative pressure of $40-50 \mathrm{~mm} \mathrm{Hg}$ supplied by a surgical pump.

\section{Quantitative Cytology}

Following bronchoalveolar lavage, the volume of fluid recovered was determined and the total cell count determined using a Coulter counter model ZBI. The cells were then sedimented by centrifugation $(1500 \times \mathrm{g}, 5 \mathrm{~min})$. Cellular spreads were stained with Wright's staining methods and a differential count was made on 500 cells from each horse.

\section{Lung Tissues for Histological Examinations}

At post-mortem several lung sections were selected for histological examinations. Four representative samples from each horse lung (left and right) were taken from: 1) the margins of the apical, 2) ventral, 3) dorsal, and 4) diaphragmatic lobes. Three sections were obtained from the trachea: 1) upper trachea (first 2 rings), 2) middle, and 3) lower (the carina).

Large and small airway sections were obtained starting from the primary bronchus down to small terminal bronchi of the diaphragmatic lobe. Lung tissue blocks were prepared and stained with routine hematoxylin and eosin. 
Table 2: Mean ventilation values from normal and abnormal horses (Pre-Bal)

\begin{tabular}{|c|c|c|c|c|}
\hline \multirow[t]{2}{*}{1} & \multicolumn{4}{|c|}{ Groups } \\
\hline & 1 & 2 & 3 & 4 \\
\hline$n$ & 11 & 4 & 7 & 2 \\
\hline B. W. (kg) & $444.4 \pm 15.2^{+}$ & $426.5 \pm 35.4$ & $443.6 \pm 24.8$ & $542.0 \pm 46$ \\
\hline$\left[\mathrm{N}_{2} \%\right]$ end & $0.95 \pm 0.10$ & $2.88 \pm 0.60^{*}$ & $3.94 \pm 0.85^{*}$ & $3.65 \pm 2.65^{*}$ \\
\hline FRC (L/100 kg) & $4.85 \pm 0.22$ & $6.76 \pm 0.72$ & $6.69 \pm 1.29$ & $3.75 \pm 0.80$ \\
\hline$V_{T}(L)$ & $4.59 \pm 0.23$ & $4.03 \pm 0.46$ & $4.38 \pm 0.59$ & $5.31 \pm 0.20$ \\
\hline$f$ (breaths/min) & $11.56 \pm 1.54$ & $13.6 \pm 1.34$ & $13.7 \pm 3.05$ & $12.1 \pm 4.50$ \\
\hline$\dot{\mathrm{V}}_{1}(\mathrm{~L} / \mathrm{min})$ & $50.4 \pm 5.00$ & $53.28 \pm 5: 46$ & $58.9 \pm 12.5$ & $65.0 \pm 26.3$ \\
\hline$t_{E} / t_{1}$ & $1.20 \pm 0.12$ & $1.16 \pm 0.08$ & $1.24 \pm 0.16$ & $1.37 \pm 0.11$ \\
\hline
\end{tabular}

+ Mean \pm standard error of the mean

* Significantly different from group $1(P<.05)$

Table 3: Mean pulmonary mechanical values in normal and abnormal horses (Pre-BAL)

\begin{tabular}{|cl|r|r|r|r|}
\hline & & & & & \\
\hline \multirow{2}{*}{1} & total $^{\delta}$ & $2.06 \pm 0.16^{+}$ & $2.67 \pm 0.42$ & $180.9 \pm 31.2$ & $4.83 \pm 0.70$ \\
& lower $_{3}$ & $1.82 \pm 0.14$ & $0.46 \pm 0.14$ & $27.7 \pm 0.8$ & $2.91 \pm 0.27$ \\
& total & $2.12 \pm 0.43$ & $3.82 \pm 1.21$ & $289.8 \pm 115.4$ & $5.44 \pm 0.97$ \\
\multirow{2}{*}{3} & lower & $1.97 \pm 0.47$ & $1.16 \pm 0.22$ & $59.4 \pm 8.6$ & $2.40 \pm 0.36$ \\
& total & $1.8 \pm 0.37$ & $3.06 \pm 0.65$ & $206.7 \pm 68.2$ & $6.96 \pm 2.65$ \\
\multirow{2}{*}{4} & lower & $1.7 \pm 0.32$ & $1.07 \pm 0.38$ & $93.1 \pm 44.1$ & $5.21 \pm 2.49$ \\
& total & $1.0 \pm 0.16$ & $7.73 \pm 1.26^{*}$ & $598.2 \pm 420.5^{*}$ & $14.6 \pm 7.14^{*}$ \\
& lower & $0.91 \pm 0.25$ & $5.83 \pm 1.12^{*}$ & $477.6 \pm 332.6^{*}$ & $12.5 \pm 6.99^{*}$ \\
\hline
\end{tabular}

+ Mean \pm standard error of mean

* Significantly different from group $1(P<.05)$

$\delta$ Total transpulmonary pressure, i. e. external nares to pleural pressure.

Lower transpulmonary pressure, i. e., trachea to pleural pressure.

Table 4: Mean blood gas values ( $\mathrm{mmHg}$ ) from normal and abnormal horses breathing room air (Pre-Bal)

\begin{tabular}{|l|c|c|c|c|}
\hline & \multicolumn{5}{|c|}{ Groups } \\
\cline { 2 - 5 } & 1 & 2 & 3 & 4 \\
\hline$n$ & 11 & 4 & 7 & 2 \\
$\mathrm{n} \mathrm{H}_{\mathrm{a}}$ & $7.38 \pm 0.01^{+}$ & $7.36 \pm 0.006$ & $7.38 \pm 0.008$ & $7.39 \pm 0.005$ \\
$\mathrm{P}_{\mathrm{CO}}$ & $43.0 \pm 1.2$ & $41.8 \pm 3.5$ & $42.4 \pm 1.17$ & $41.5 \pm 0.5$ \\
$\mathrm{P}_{\mathrm{a}} \mathrm{O}_{2}$ & $89.4 \pm 1.6$ & 85.5 & $61.0 \pm 8.0^{*}$ \\
$\mathrm{P}_{\mathrm{A}} \mathrm{O}_{2}$ & $96.95 \pm 1.39$ & $96.1 \pm 3.4$ & $83.6 \pm 4.6$ & $93.36 \pm 0.18$ \\
$\mathrm{~A}-\mathrm{aDO}_{2}$ & $7.50 \pm 1.26$ & $11.18 \pm 2.95$ & $93.1 \pm 1.5$ & $32.36 \pm 7.82^{*}$ \\
\hline
\end{tabular}

+ Mean \pm standard error of the mean

* Significant difference between group 1 and $5(P<.05)$

Table 5: Mean recovery of fluid and cells from broncho-alveolar lavage on normal horses and horses with respiratory diseases

\begin{tabular}{|c|c|c|c|c|}
\hline Group & $n$ & $\begin{array}{c}\text { Total Cell } \\
\text { Recovery } \\
\times 10^{8}\end{array}$ & $\begin{array}{c}\text { Cell Viability } \\
\%\end{array}$ & $\begin{array}{c}\text { Lavage fluid } \\
\text { Recovery from } \\
500 \mathrm{ml} \\
\%\end{array}$ \\
\hline $1 \mathrm{~A}$ & 8 & $3.7 \pm 0.45^{+}$ & $90.7 \pm 0.7$ & $55.9 \pm 7.4$ \\
$1 \mathrm{~B}$ & 3 & $2.02 \pm 0.25$ & $89.5 \pm 0.5$ & $66.0 \pm 4.9$ \\
2 & 4 & $3.26 \pm 0.85$ & $86.5 \pm 1.2$ & $50.5 \pm 3.5$ \\
3 & 7 & $7.0 \pm 1.75$ & $89.0 \pm 3.1$ & $52.5 \pm 3.2$ \\
4 & 2 & $5.1 \pm 3.37$ & $92.5 \pm 2.5$ & $24.4 \pm 2.4$ \\
\hline
\end{tabular}

+ Mean \pm standard error of the mean.
This was not surprising as little morphological changes were observed in the small airways except some degree of peribronchiolar eosinophilic infiltration.

Although further work is needed in establishing the role of immune effector cells in the BAL fluid of COPD horses, the increased proportion of lymphocytes and neutrophils in our diseased horses seems to indicate a stage or a peculiar pattern of the small airway diseases. In many lung diseases large proportions of lymphocytes and neutrophils in the BAL are representative of hypersensitivity pneumonitis where histologically alveolar structures are massively infiltrated with either lymphocytes or neutrophils $(10,11,16)$. 
Table 6: Mean cell differential (\%) in lung lavage fluid of normal and diseased horses

\begin{tabular}{|c|c|c|c|c|c|c|}
\hline Group & $\begin{array}{l}\text { Macro- } \\
\text { phages }\end{array}$ & $\begin{array}{l}\text { Lympho- } \\
\text { cytes }\end{array}$ & $\begin{array}{c}\text { Neutro- } \\
\text { phils }\end{array}$ & $\begin{array}{l}\text { Mast } \\
\text { cells }\end{array}$ & $\begin{array}{l}\text { Eosino- } \\
\text { phils }\end{array}$ & $\begin{array}{c}\text { Epithelial } \\
\text { cells }\end{array}$ \\
\hline $1 \mathrm{~A}$ & $\begin{array}{r}48.5^{+} \\
+\quad 2.5\end{array}$ & $\begin{array}{r}35.3 \\
\pm \quad 2.3\end{array}$ & $\begin{array}{r}6.2 \\
+\quad 2.4\end{array}$ & $\begin{array}{r}5.2 \\
+0.82\end{array}$ & $\begin{array}{ll} & 2.5 \\
\pm & 0.96\end{array}$ & $\begin{aligned} & 2.3 \\
\pm & 1.37\end{aligned}$ \\
\hline $1 \mathrm{~B}$ & $\begin{array}{c}34.1 \\
\pm \quad 0.27\end{array}$ & $\begin{array}{c}29.0 \\
\pm \quad 1.09\end{array}$ & $\begin{array}{r}6.1 \\
+\quad 2.8\end{array}$ & $\begin{array}{c}5.0 \\
\pm 1.24\end{array}$ & $\begin{array}{r}20.2 \\
+\quad 4.8\end{array}$ & $\begin{array}{r}4.5 \\
\pm 1.6\end{array}$ \\
\hline 2 & $\begin{array}{r}35.8 \\
+\quad 5.0\end{array}$ & $\begin{array}{c}43.0 \\
+\quad 1.46\end{array}$ & $\begin{array}{r}9.2 \\
\pm \quad 3.4\end{array}$ & $\begin{array}{l}3.0 \\
\pm 1.27\end{array}$ & $\begin{array}{ll} & 7.6 \\
+ & 5.17\end{array}$ & $\begin{array}{c}1.4 \\
\pm 0.37\end{array}$ \\
\hline 3 & $\begin{array}{r}26.7^{*} \\
\pm \quad 5.9\end{array}$ & $\begin{array}{r}36.4 \\
+\quad 8.66\end{array}$ & $\begin{array}{r}28.0^{*} \\
\pm 11.2\end{array}$ & $\begin{array}{c}3.3 \\
\pm 0.82\end{array}$ & $\begin{array}{ll} & 1.8 \\
+ & 0.96\end{array}$ & $\begin{array}{r}3.7 \\
\pm \quad .5\end{array}$ \\
\hline 4 & $\begin{array}{c}14.0^{*} \\
\pm \quad 7.3\end{array}$ & $\begin{array}{r}23.0 \\
\pm \quad 4.1\end{array}$ & $\begin{array}{r}46.8^{*} \\
\pm 13.2\end{array}$ & $\begin{array}{r}7.4 \\
\pm 2.5\end{array}$ & $\begin{array}{r}1.8 \\
+\quad 1.8\end{array}$ & $\begin{array}{r}7.0 \\
+1.7\end{array}$ \\
\hline
\end{tabular}

+ Mean \pm S. E.M.

* Significant difference between groups $1 \mathrm{~A}$ and 3 and $1 \mathrm{~A}$ and $4(P<.05)$

In contrast, our diseased horses had little changes in the alveolar interstitium. Nodular lymphoid hyperplasia or lymphoid cuffing in the small airway adventitia was more characteristic of the lymphocytic group, while marked inflammatory cell infiltration of the entire airway walls was more specific to severely affected horses in groups 3 and 4 . In this study, post-mortem examination of each experimental horse was without doubt the most valuable source of reference. Without this information, it would have been almost impossible to classify or categorize groups of horses and to make useful assessment of their PFT, BAL and lung

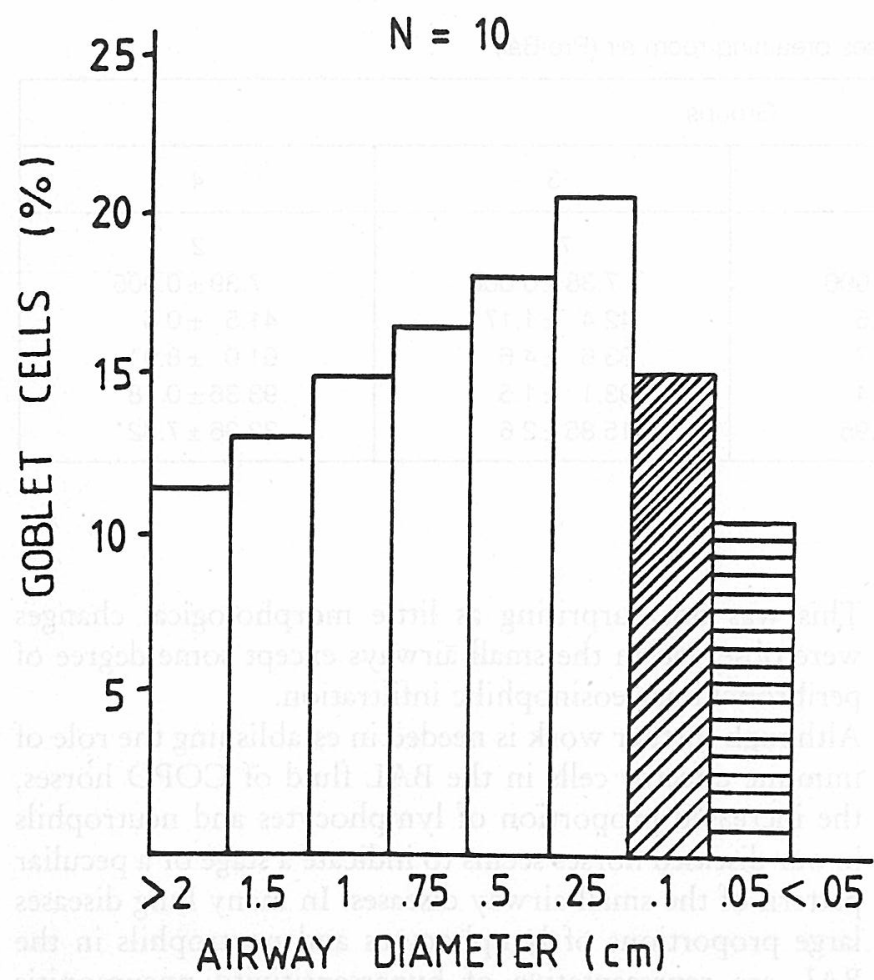

Fig. 1: Frequency distribution of mean percent goblet cells at various diameters of airway from normal horses (hatching indicates main site of mucus producing cell hyperplasia).
GROUP 3

GROUP 4

GROUP 5

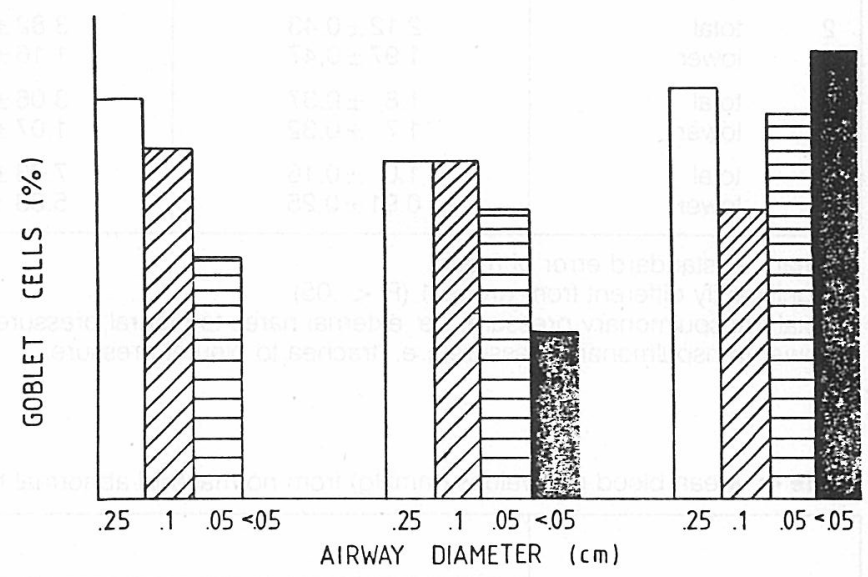

Fig. 2: Frequency distribution of mean percent goblet cells from airway less than $0.25 \mathrm{~cm}$ in diameter (hatching and shaded area indicate the small airway sites affected by mucus producing cell proliferation).

biopsy results. In gross pathologic examination, horses suffering from chronic airway disease had few abnormalities. On the basis of subjective observations, severely affected horse lungs tended to remain more inflated when the thorax was opened, i. e. they maintained a higher residual volume.

Histologically, quantitative analysis of the morphologic abnormalities of the airways and lung parenchyma provided valuable information in the progression and staging of the lesions encountered in the lung of horses with chronic airway diseases. Morphologic data showed that the first changes that occurred as the disease in small airways increased (group 2), were the appearance of hyperplasia of the airway epithelium, with mild chronic inflammatory infiltrate, lymphoid hyperplasia and slight goblet cell hyperplasia in bronchioles but not in terminal bronchioles. As the pathological process progressed (groups 3 and 4), previous lesions were amplified and there was an increase in connective tissue and goblet cell metaplasia and excess mu- 
cus exudate production became an important feature in severely diseased horses (group 4). Although there is little study in the veterinary literature showing the transition between healthy and chronic small airway diseases, our pathological findings, as well as that of others $(3,15,21)$, give enough evidence to suggest that the COPD horse had morphological lesions mainly concentrated in the bronchioles (Figs. 1-2). There was also little pathologic resemblance to the chronic bronchitis and emphysema of man. In retrospect, the present study has given accurate and reliable information on methods used to identify functional and structural abnormalities as well as cellular components involved within the equine lung in health and disease. It was also demonstrated that a good correlation was obtain-

\section{References}

1. Alexander, A.F. (1959): Chronic Alveolar Emphysema in the Horse. American Review of Respiratory Diseases 80, 141-146.

2. Bolz, W., and Bieniek, H. (1974): Lungenfunktionsprüfungen beim chronisch alveolaren Lungenemphysem des Pferdes. I. Oxymetrische Untersuchungen, Mh. Tierheilk. 13, 213-222.

3. Breeze, R. G. (1979): Heaves, The Veterinary Clinics of North America (Large Animal Practice). Vol. 1, No. 1, W. B. Saunders Co., Philadelphia, ad 219-230.

4. Eyre, P. (1972 b): Equine Pulmonary Emphysema: A Bronchopulmonary Mould Allergy. Veterinary Record 91, 134-140.

5. Gerber, H. (1973): Chronic Pulmonary Disease in the Horse. Equine Veterinary Journal 5, 26-33.

6. Gillespie, J.R., and Tyler, W.S. (1969): Chronic Alveolar Emphysema in the Horse. Advance in Veterinary Sciences and Comparative Medicine 13, 59-99.

7. Gillespie, J.R., Tyler, W.S., and Eberly, V.R. (1966): Pulmonary Ventilation and Resistance in Emphysematous and Control Horses. Journal Apply of Physiology 21, 416-422.

8. Hajer, $R$. (1979): Enkele aspecten van het sputumonderzoek van paarden met aandoening de voorst luchtwegen. Utrecht, Rijksuniversiteit, Proefschrift.

9. Hanna, C. J., Eyre, P., Wells, P. W., and McBeath, D. G. (1982): Equine Immunology 2: Immunopharmacology - Biochemical Basis of Hypersensitivity. Equine Veterinary Journal 14, 16-24.

10. Hogg, J. C., Macklem, P. T., and Thurlbeck, W. N. (1968): Site and Nature of Airway Obstruction in Chronic Obstructive Lung Disease. New England Journal of Medicine 278, 1355-1360.

11. Hunninghake, G.W., Fulmer, J.D., Young, R. C., Gadek, J.E., and Crystal, R. G. (1979): Localization of the Immune Response in Sarcoidosis. American Review of Respiratory Diseases 120, 44-57.

12. Koegh, B., Cline, B., Rust, M., Hunninghake, G., Meier-Sydow, J., and Crystal, R., (1981):Clinical Staging of Patients with Idiopathic Pulmonary Fibrosis. American Review of Respiratory Desease 123, 89 A.

13. Littlejohn, A. (1979): Chronic Obstructive Pulmonary Disease in Horses. The Veterinary Bulletin 49, 907-917.

14. Lowell, F. C. (1964): Observations on Heaves. An Asthma-Like Syndrome in the Horse. Journal of Allergy 35, 322-330. ed between pathological data and the nitrogen washout test and cell differential counts from BAL. Although pulmonary function testing correlated poorly with bronchoalveolar lavage, it is certain that both methods in assessing lung dysfunction would be complementary and supportive in clinical use. Furthermore, BAL appears to be an ideal clinical tool permitting serial lavage without major risk; cells recovered may help in following the status of the inflammatory process within the lung or assessing the activity of the disease. Possibly, of even greater importance than its clinical application is that BAL can further provide new insights into pulmonary biochemistry such as non-cellular components related to the inflammatory and immune mechanisms within the horse lung.
15. Muylle, E., and Oyaert, W. (1973): Lung Function Tests in Obstructive Pulmonary Disease in Horses. Equine Vet. J. 5, 37-44.

16. Nicholls, J. (1978): A Pathological Study of Chronic Pulmonary Disease in the Horse. Ph. D. Thesis, University of Glasgow.

17. Rossi, G.A., Hunninghake, G.W., and Crystal, R. G. (1982): Evaluation of Inflammatory and Immune Processes in the Interstitial Lung Disorders: Use of Brochoalveolar Lavage. In Cunning, G., and Bonsig. nore, G. (ed.): Cellular Biology of the Lung. Plenum Press, New York, 107-140.

18. Sasse, H. H. L. (1971): Some Pulmonary Function Tests in Horses. An Aid to the Early Diagnosis of Chronic Obstructive Pulmonary Disease (Heaves) in Horses. Doctoral Thesis, Utrecht.

19. Schatzman, U., Gerber, H., Straub, R., Lazary, S., and Deweck, A.L. (1973): Applied Immunology in Chronic Pulmonary Conditions. Proceeding 3rd International Conference of Equine Infectious Diseases, Paris, 448-457.

20. Spörri, H., and Denac, M. (1970): Der Stickstoffeinwaschungstest im Dienste der Lungenfunktionsprüfung. Zbl. Vet. Med. A 17, 845-856.

21. Thurlbeck, W.M., and Lowell, F. C. (1964): Heaves in Horses. American Review of Respiratory Diseases 89, 82-88.

22. Valli, V.E. O., and Britton (1983): Quantitative Pathological Studies of Equine Chronic Obstructive Pulmonary Disease, in publication, 1983.

23. Willoughby, R. A., and McDonell, W.N. (1979): Pulmonary Function Testing in Horses. The Veterinary Clinics of North America (Large Animal Practice), Vol. 1, No. 1, W. B. Saunders Co., Philadelphia, 171-196.

\section{Viel, DVM, PbD}

Department of Clinical Studies

Ontario Veterinary College, University of Guelph

Guelph

Ontary, N1G2W1, Canada 